\title{
PERILAKU CARING DAN TIPE KEPRIBADIAN MAHASISWA PROFESI NERS UNIVERSITAS KLABAT
}

\author{
Frendy Fernando Pitoy \\ Sabathiny Switnes Pratasik \\ frendypitoy@gmail.com \\ sabathinypratasik@gmail.com
}

\begin{abstract}
Abstrak
Caring merupakan bentuk kepedulian berupa perhatian, penghargaan dan kasih sayang terhadap seseorang yang ditunjukkan melalui perilaku. Ada beberapa faktor yang mempengaruhi bagaimana seseorang berperilaku, salah satunya adalah faktor internal yaitu kepribadian. Tujuan dari penelitian ini untuk mengetahui apakah ada perbedaan perilaku caring yang signifikan berdasarkan tipe kepribadian pada mahasiswa profesi ners Universitas Klabat. Metode yang digunakan dalam penelitian ini adalah Comparative Study dengan menggunakan teknik Consecutive Sampling. Responden yang setujuh berpartisipasi pada penelitian ini adalah mahasiswa profesi ners fakultas keperawatan sebanyak 100 responden. Dari hasil penelitian didapatkan gambaran perilaku caring mahasiwa profesi ners yang paling banyak berada pada kategori perilaku caring yang baik yaitu 57 (57\%) responden dan untuk gambaran tipe kepribadian didapatkan mayoritasnya mempunyai tipe kepribadian sanguinis 33 (33\%) responden. Untuk hasil analisis perbandingan didapatkan hasil yang menunjukkan bahwa tidak ada perbedaan perilaku caring yang signifikan antara tipe kepribadian dengan nilai $\mathrm{p}=0.216$ $(\alpha<0,05)$. Penelitian menyimpulkan bahwa prilaku caring yang diberikan oleh mahasiswa tidak berbeda berdasarkan tipe kepribadian. Diharapkan penelitian ini dapat menjadi dasar kepada setiap orang khususnya mahasiswa perawat ataupun perawat yang sudah bekerja di Rumah Sakit agar dapat mempertahankan perilaku caring yang baik.
\end{abstract}

Kata kunci : Perilaku caring, tipe kepribadian, mahasiswa perawat

\section{Latar Belakang}

Caring merupakan jenis hubungan dan transaksi yang diperlukan antara pemberi dan penerima asuhan untuk meningkatkan dan melindungi pasien sebagai manusia, sehingga akan memengaruhi kesembuhan pasien (Teting, Natalia, \& Ermayani, 2018). Menurut Potter dan Perry (2012), Keperawatan merupakan profesi yang mengedepankan sikap "care", atau kepedulian, dan kasih sayang terhadap klien. Dalam hal ini, perilaku caring bukan hanya ditunjukan oleh perawat yang sudah bekerja tetapi juga para mahasiswa-mahasiswa perawat yang sedang menempuh pendidikan keperawatan yang akan menjadi seorang perawat.

Penelitian Aiken menunjukkan persentase perawat yang memiliki kualitas pelayanan caring yang buruk terdapat pada Negara Irlandia 11\%, dan Yunani 47\%. Di Indonesia sendiri ada beberapa penelitian yang menunjukan perilaku caring perawat di rumah sakit, diantaranya ada penelitian yang dilakukan oleh Zees (2011) pada 120 perawat pelaksana didapatkan perilaku caring perawat pelaksana $53,3 \%$ berada pada kategori perilaku caring yang kurang dan $46,7 \%$ berada pada kategori perilaku caring yang baik.

Penerapan perilaku caring bukan hanya diterapkan oleh perawat yang sudah bekerja, tetapi juga harus diterapkan oleh mahasiswa keperawatan yang nantinya akan menjadi seorang perawat. Menurut Siwantoro (2014), perilaku caring yang belum optimal terjadi juga pada mahasiswa keperawatan. Hal itu didukung dengan hasil penelitiannya yang menunjukkan bahwa dari 15 responden yang berperilaku caring dengan baik hanya $6(40 \%)$ responden sedangkan 
sebagian besar $9(60 \%)$ responden kurang berperilaku caring. Dari hasil penelitian tersebut menunjukkan bahwa penerapan perilaku caring di Indonesia masih terbilang kurang. Kurangnya perilaku caring dapat disebabkan oleh beberapa faktor. Menurut Gibson dalam Rahayu dan Sulistiawati (2018), salah satu faktor yang sangat penting mengapa seseorang berprilaku adalah faktor psikologis yaitu kepribadian.

Kepribadian adalah pola watak yang relative permanen dan karakter unik dimana keduanya memiliki konsistensi dan keunikan pada perilaku individu atau seseorang (Feist $\&$ Feist, 2014). Menurut Hippocrateus (460370 SM) terdapat sifat-sifat didalam tubuh manusia yaitu sifat kering terdapat dalam chole (empedu kuning), sifat basah terdapat dalam melanchole (empedu hitam), sifat dingin terdapat dalam phlegma (limpa), dan sifat panas terdapat dalam sanguinis (darah) (Jaenudin, 2012).

Selanjutnya Galenus (129-200 SM) mengembangkan pendapat Hippocrates tersebut. Galenus berpendapat apabila salah satu dari cairan-cairan tubuh (empedu kuning, empedu hitam, limpa dan darah) lebih banyak, bararti suatu individu mempunyai ciri khas (tipe kepribadian) tertentu. Sehingga Galenus membagi tipe kepribadian seseorang menjadi empat tipe yaitu Sanguinis, Koleris, Melankolis dan Plegmatis (Jaenudin, 2012)

Pendapat Hippocrateus dan Galenus kemudian disempurnakan oleh Florence Littauer. Florence menjelaskan bagaimana ciri-ciri tiap kepribadian. Seorang Sanguinis merupakan seseorang yang suka bicara, suka menolong, mudah bahagia namun mudah sedih, berantakan, emosional, dan kekanakkanakan. Individu yang mempunyai kepribadian koleris sangat menyukai tantangan, hidup untuk pencapaian, berbakat menjadi seorang pemimpin karena dapat mengatur segala sesuatu dengan cepat, mudah menjalin pertemanan, pekerja keras dan disiplin. Seorang melankolis mempunyai ciri-ciri pemikir, introvert, melakukan segala sesuatu dengan sempurna, sensitif, tenang dan merupakan seorang analis yang handal.
Seorang plegmatis mempunyai kepribadian yang menyenangkan, dapat menyesuaikan diri dengan lingkungan, menjadi pendengar yang baik, menikmati hidup dan tidak terlalu menyukai tantangan (Littauer dalam Hamidah, 2018).

Penelitian Prima, Astikasari dan Byba (2016) kepada perawat di salah satu rumah sakit Kediri menunjukan bahwa dari 30 responden diketahui paling banyak memiliki tipe kepribadian sanguinis yaitu 14 responden $(46 \%)$. Begitu juga dengan penelitian yang dilakukan oleh Thadea, Suhartono dan Putra (2018) yang menunjukkan bahwa dari 100 responden didominasi oleh tipe kepribadian sanguinis $35 \%$ diikuti dengan koleris $13 \%$, melankolis $27 \%$, dan plegmatis $25 \%$. Kedua hasil penelitian sebelumnya berbeda dengan hasil penelitian dari Fatningsaliska, Bidjuni dan Wowiling (2015) pada mahasiwa di TKK SMFK Universitas Sam Ratulangi Manado dengan hasil persentase tipe kepribadian melankolis yang paling mendominasi yaitu sebanyak 21 responden $(51,1 \%)$ lalu diikuti dengan tipe kepribadian sanguinis 9 responden $(22 \%)$, plegmatis 7 responden $(17,1 \%)$, dan koleris 4 responden $(9,8 \%)$.

Berdasarkan pemaparan diatas, perilaku caring setiap orang dapat berbedabeda tergantung pada kepribadian mereka dan bagaimana mereka dibekali untuk berperilaku caring. Pada hasil observasi peneliti kepada sebagian mahasiswa Profesi Ners Universitas Klabat, mereka memiliki perilaku caring yang berbeda-beda, ada yang sangat memperlihatkan perilaku caring mereka dalam melakukan asuhan keperawatan tetapi ada juga yang belum memperlihatkan perilaku caring secara optimal. Penelitian tentang perbandingan perilaku caring dan tipe kepribadian juga masih jarang dilakukan, sehingga membuat peneliti tertarik melakukan penelitian untuk mengetahui apakah ada perbedaan perilaku caring antara keempat tipe kepribadian yaitu sanguinis, koleris, melannkolis, dan plegmatis pada mahasiswa perawat Profesi Ners Universitas Klabat. 


\begin{abstract}
Metodologi
Metode yang digunakan dalam penelitian ini adalah Comparative Study dimana rancangan ini difokuskan untuk membandingkan persamaan dan perbedaan sebagai fenomena untuk mencari faktor atau situasi yang menyebabkan perbedaan atau persamaan pada kelompok subjek tanpa adanya suatu perlakuan dari peneliti
\end{abstract} (Nursalam, 2015). Variabel dalam penelitian ini dibagi menjadi dua yaitu variabel terikat (dependent variable) dan variabel bebas (independent variable). Variabel bebas dalam penelitian ini adalah tipe kepribadian, variabel terikat adalah prilaku caring.

Teknik sampling dalam penelitian ini adalah Consecutive sampling dimana teknik penetapan sampel dengan menetapkan subjek yang memenuhi kriteria penelitian dimasukkan dalam penelitian sampai kurun waktu yang ditentukan oleh peneliti (Nursalam, 2015). Pada penelitian ini sampel yang diambil berjumlah 100 orang berdasarkan responden yang sudah mengisi kuesioner online yang telah di bagikan sampai pada waktu yang sudah ditentukan.

Instrumen penelitian berupa kuesioner mengenai perilaku caring dan tipe kepribadian. Kuesioner perilaku caring yang digunakan terdapat 36 pernyataaan yang dikembangkan oleh Rika (2013), dengan nilai uji reliabilitas 0,845 . Responden mengisi kuesioner dengan pilihan skala Likert yaitu "Tidak Pernah (TP) diberi nilai 1, Kadang-Kadang (KK) diberi nilai 2, Sering (SR) diberi nilai 3, dan Selalu (SL) diberi nilai 4 . Terdapat 36 pernyataan dengan nilai terendah 36 dan nilai tertinggi 144. Hasil yang didapat memiliki interpretasi perilaku caring baik dalam interval 109-144, perilaku caring cukup dalam interval 73-108, dan perilaku caring kurang dalam interval 3672. Sedangkan kuesioner tipe kepribadian yang digunakan diadaptasi dari pola-pola kepribadian oleh Lana Bateman yang terdapat dalam buku Personality Plus karya Florence Littaeur (2000). Kuesioner ini terdiri dari 40 pernyataan dimana setiap nomor terdapat empat definisi sifat yang menggambarkan keempat kepribadian yaitu sanguinis, koleris, melankolis dan plegmatis. Responden diharuskan memilih satu dari keempat definisi sifat tersebut yang paling mencerminkan kepribadian yang dimiliki.

Ppengumpulan data dilakukan pada saat wabah Covid-19 sehingga pengumpulan data harus dilakukan secara online. Saat dilakukan pengumpulan data, prinsip etik telah menjadi pertimbangan peneliti. Peneliti menjelaskan mengenai pengisian form informed consent yang merupakan bukti bahwa responden bersedia ikut serta dalam penelitian dan diisi sepenuhnya oleh keinginan responden sendiri. Penelitian yang dilakukan juga secara pasti tidak berbahaya dan tidak merugikan responden. Manfaat penelitian menguntungkan kedua pihak dengan seimbang baik pihak peneliti maupun pihak responden, dan secara adil tanpa membeda-bedakan setiap responden. Peneliti telah bersikap jujur dengan tidak ada data yang direkayasa, serta menepati janji yang disampaikan kepada responden sebelum melakukan penelitian. Peneliti menyalurkan instrumen penelitian menggunakan Microsoft form dan kemudian dibagikan kepada mahasiswa Profesi Ners Universitas Klabat mulai dari tanggal 5 April 2020 - 17 April 2020. Setelah tanggal 17 April 2020 peneliti mengumpulkan data-data yang telah diisi responden dari microsoft form dan dipindahkan ke microsoft excel untuk dilakukan analisa data. Analisa data dilakukan menggunakan SPSS untuk mencari gambaran dari masing-masing variabel dengan rumus frekuensi persentase dan untuk analisa perbandingan yang digunakan adalah uji ANOVA setelah ditemukan data kedua variabel berdistribusi normal.

\section{Hasil dan Pembahasan}

Tabel 1. Gambaran perilaku caring pada mahasiswa profesi ners Universitas Klabat

\begin{tabular}{ccc}
\hline $\begin{array}{c}\text { Perilaku } \\
\text { Caring }\end{array}$ & $\boldsymbol{f}$ & Persen (\%) \\
\hline Baik & 57 & 57.0 \\
Cukup & 43 & 43.0 \\
Kurang & 0 & 0 \\
Total & $\mathbf{1 0 0}$ & $\mathbf{1 0 0}$ \\
\hline
\end{tabular}

Tabel 1 menunjukan bahwa dari total 100 responden yang dilakukan penelitian 
terdapat $57(57 \%)$ responden memiliki perilaku caring yang baik, $43(43 \%)$ responden memiliki perilaku caring yang cukup, sedangkan tidak ada responden yang memiliki perilaku caring dalam kategori kurang.

Hasil penelitian menunjukkan bahwa perilaku caring setiap orang dapat berbedabeda, tergantung pribadi setiap orang dan bagaimana mereka dibekali untuk berperilaku peduli pada sesama. Dalam perguruan tinggi keperawatan selalu dibekali dengan perilaku caring yang baik, bagaimana melakukannya dan apa manfaatnya, sehingga dalam penelitian ini didapatkan mayoritasnya berada pada kategori baik serta tidak terdapat perilaku caring dalam kategori kurang. Hasil penelitian ini sejalan dengan hasil penelitian yang dilakukan oleh Rika (2013) pada perawat di RSUD Dr. Tengku Masyur Tangjungbalai dengan hasil menunjukan bahwa yang mendominasi yaitu perilaku caring dalam kategori baik sebanyak 29 $(52,7 \%)$ responden, diikuti dengan 26 $(27,3 \%)$ responden dalam kategori perilaku caring yang cukup, dan tidak ada responden yang nenunjukkan perilaku caring dengan katergori kurang. Berbeda dengan hasil penelitian yang dilakukan oleh Siwantoro (2014) pada mahasiswa ners Dian Husada dengan hasil didapatkan mahasiswa yang berperilaku caring dengan baik hanya 6 (40\%) responden, sedangkan sebagian besar $9(60 \%)$ responden kurang berperilaku caring.

Tabel 2. Gambaran tipe kepribadian pada mahasiswa Profesi Ners Universitas Klabat

\begin{tabular}{ccc}
\hline Tipe Kepribadian & $\boldsymbol{f}$ & Persen (\%) \\
\hline Sanguinis & 29 & $29 \%$ \\
Koleris & 10 & $10 \%$ \\
Melankolis & 28 & $28 \%$ \\
Plegmatis & 33 & $33 \%$ \\
Total & $\mathbf{1 0 0}$ & $\mathbf{1 0 0}$ \\
\hline
\end{tabular}

Tabel 2 menunjukan bahwa dari total 100 responden terdapat $29(29 \%)$ responden memiliki tipe kepribadian sanguinis, 10 $(10 \%)$ responden memiliki tipe kepribadian koleris, 28 (28\%) responden memiliki tipe kepribadian melankolis, dan 33 (33\%) responden memiliki tipe kepribadian plegmatis.

Dari hasil penelitian ini ditemukan tipe kepribadian terbanyak berada pada tipe kepribadian plegmatis 33 (33\%). Berdasarkan observasi peneliti pada mahasiswa Profesi Ners Universitas Klabat, sebagian besar mahasiswa memiliki tipe kepribadian plegmatis karena kebanyakan mahasiwa termotivasi untuk memberikan pelayanan yang baik kepada pasien saat praktek dirumah sakit, ingin memiliki hubungan saling percaya dengan pasien, hubungan persahabatan yang baik, sehingga menghasilkan perilaku caring yang baik. Hal ini dapat didukung dengan perilaku caring yang berada pada kategori yang baik dikarenakan menurut Littauer dalam Hamidah (2018) seorang plegmatis mempunyai kepribadian yang menyenangkan, dapat menyesuaikan diri dengan lingkungan, menjadi pendengar yang baik, menikmati hidup dan tidak terlalu menyukai tantangan. Hasil pernelitian ini berbeda dengan hasil penelitian dari Fatningsaliska, Bidjuni dan Wowiling (2015) pada mahasiwa di TKK SMFK Universitas Sam Ratulangi Manado dengan hasil yang didapat tipe kepribadian melankolis paling mendominasi yaitu sebanyak $21 \quad(51,1 \%)$ responden, lalu diikuti dengan tipe kepribadian sanguinis $9(22 \%)$ responden, tipe kepribadian plegmatis $7 \quad(17,1 \%)$ responden, dan tipe kepribadian koleris 4 $(9,8 \%)$ responden.

Tabel 3. Perbandingan perilaku caring berdasarkan tipe kepribadian mahasiswa Profesi Ners Universitas Klabat

\begin{tabular}{cccccc}
\hline & $\begin{array}{c}\text { Sum of } \\
\text { Squares }\end{array}$ & $\boldsymbol{d} \boldsymbol{f}$ & $\begin{array}{c}\text { Mean } \\
\text { Square }\end{array}$ & $\boldsymbol{F}$ & Sig. \\
\hline Betwee & 879.617 & 3 & 293.20 & 1.51 & .21 \\
$n$ & & & 6 & 5 & 6 \\
Groups & & & & & \\
\hline Within & 18584.49 & 9 & 193.58 & & \\
Groups & 3 & 6 & 8 & & \\
\hline Total & $\mathbf{1 9 4 6 4 . 1 1}$ & $\mathbf{9}$ & & & \\
& $\mathbf{0}$ & $\mathbf{9}$ & & & \\
\hline
\end{tabular}

Tabel 3 menunjukkan hasil uji Comparative dengan menggunakan Anova 
mengenai perbandingan perilaku caring berdasarkan tipe kepribadian pada mahasiswa profesi ners Universitas Klabat. Dari uji Anova terlihat nilai signifikan $p$ value $=0,216$ yang berarti $\alpha>0,05$, hal ini menunjukan bahwa tidak ada perbedaan perilaku caring yang signifikan antara tipe kepribadian.

Hasil mengimplikasikan bahwa perilaku caring tidak dibedakan berdasarkan tipe kepribadian dari mahasiswa. Hal ini dibuktikan dengan hasil analisa dimana mayoritas responden berperilaku caring dalam kategori baik walaupun tipe kepribadian responden berbeda-beda. Sebagai seorang perawat, caring merupakan yang hal yang terpenting dalam melaksanakan kewajiban sebagai seorang perawat. Peneliti menemukan masalah dalam mencari referensi pendukung dikarenakan minimnya penelitian yang dilakukan mengenai perbandingan prilaku caring berdasarkan tipe kepribadian. Hasil dari penelitian ini dikuatkan oleh teori Jane Watson dalam Kozier, Erb, Berman dan Snyder (2011), yang menyatakan bahwa caring adalah nilai dasar dalam keperawatan. Oleh karena itu sebagai seorang perawat, walaupun mempunyai tipe kepribadian yang berbeda-beda, caring merupakan hal yang terpenting dalam melaksanakan kewajiban sebagai seorang perawat. Sehingga menurut peneliti, walaupun tipe kepribadian perawat berbeda-beda, seorang perawat harus selalu menunjukkan perilaku caring yang optimal agar mencapai tujuan keperawatan yang sebenarnya. Hal ini dibuktikan dengan hasil penelitian yang menunjukkan bahwa tidak ada perbedaan perilaku caring yang signifikan antara tipe kepribadian dari mahasiswa Profesi Ners Universitas Klabat.

\section{Keterbatasan Penelitian}

Terdapat beberapa keterbatasan yang dihadapi peneliti dalam penyusunan artikel ini. Beberapa keterbatasan tersebut yaitu: data dikumpulkan hanya secara online dikarenakan selama rentang waktu pengumpulan data keeadaan sekitar dari peneliti sedang menghadapi masalah epidemi tingkat global, sehingga peneliti tidak bisa bertemu dengan partisipan serta tidak dapat mengontrol keadaan sekitar partisipan selama pengisian kuesioner. Ada juga beberapa partisipan yang tidak bersedia dan tidak dapat dijangkau peneliti untuk mengisi kuesioner yang telah dibagikan secara online. Selain itu peneliti mengalami keterbatasan dalam mencari referensi pendukung, dikarenakan penelitian ini masih jarang dilakukan.

\section{Simpulan}

Hasil analisis data perilaku caring didapati bahwa dari 100 responden sebagian besar $57(57 \%)$ responden mahasiswa perawat profesi ners Universitas Klabat berada pada kategori yang baik. Lebih lanjut untuk hasil analisis tipe kepribadian ditemukan tipe kepribadian terbanyak berada pada tipe kepribadian plegmatis $33(33 \%)$ responden. Sedangkan hasil analisis data untuk perilaku caring berdasarkan tipe kepribadian didapati bahwa tidak ada perbedaan perilaku caring yang signifikan antara tipe kepribadian mahasiswa dengan nilai signifikan $p$-value $=0,216(\alpha>0,05)$.

\section{Rekomendasi}

Perawat tetap mempertahankan perilaku caring yang baik agar benar-benar menjadi perawat yang penuh dengan perhatian dan disegani oleh orang lain. Bagi institusi pendidikan diharapkan selalu mempertahankan pembekalan perilaku caring yang baik kepada mahasiswamahasiswa keperawatan, agar nantinya perilaku tersebut akan tetap ada dimana saja mereka berada. 


\section{Referensi}

Aiken. (2012). Psychological Testing And Assessment. 8th Edition. Boston: Allyn and Bacon.

Fatningsaliska, C. D., Bidjuni, \& H., Wowiling. (2015). Perbandingan Tingkat Stres Berdasarkan Tipe Kepribadian Hippocrates-Galenus Pada Mahasiswa yang Terlibat Organisasi Tim Kerohanian Kristen Senat Mahasiswa Fakultas Kedokteran Unsrat. ejournal Keperawatan. Volume 3 (1). Pages: 1-9. Diakses dari: https://media.neliti.com/media/publicati ons/105634-ID-perbandingan-tingkatstres-berdasarkan-t.pdf

Feist, J., \& Feist, G. J. (2014). Teori Kepribadian. Jakarta: Salemba Humanika.

Hamidah, N. (2018) Kecerdasan VisualSpasial Siswa Ditinjau Dari tipe Kepribadian Hippocrates-Galenus. Skripsi published. Diakses dari: https://repository.unej.ac.id/bitstrea $\mathrm{m} /$ handle/123456789/90648/Nur\%2 0Hamidah\%20$\% 20140210101094 \_. p d f ?$ sequence $=$ 1

Jaenudin, U. (2012). Psikologi Kepribadian. Bandung: CV Pustaka Setia.

Kozier, B., Erb, G., Berman, S., \& Snyder, S. (2011). Buku Ajar Fundamental Keperawatan Konsep, Proses, dan Praktik. Edisi 7 Volume 1. Jakarta: EGC.

Littauer dalam Hamidah, N. (2018). Kecerdasan Visual-Spasial Siswa Ditinjau Dari Tipe Kepribadian Hippocrates-Galenus. Skripsi Publised. Diakses dari: http://repository.unej.ac.id/bitstream/ha ndle/123456789/90648/Nur\%20Hamid ah\%20-

$\% 20140210101094$.pdf?sequence $=1 \&$ isAllowed $=\mathrm{y}$
Nursalam. (2015). Metodologi Penelitian Ilmu Keperawatan (4 ed.). Jakarta: Salemba Medika.

Potter, P. A., \& Perry, A. G. (2012). Buku Ajar Fundamental Keperawatan: Konsep, Proses dan Praktek. Jakarta: EGC.

Prima, D., Astikasari, N., \& Beyba, M. (2016). Relation of Personality Type According to Hippocrates with Implementation of Therapeutic Communication Nurse for Patient in the Leprosy Hospital in Kediri. Journal of Applied Environmental and Biological Sciences. Volume 6 (12). Pages: 104-107. Diakses dari:

https://www.textroad.com/pdf/JAEBS/J .\%20Appl.\%20Environ.\%20Biol.\%20S ci.,\%206(12)104-107,\%202016.pdf

Rahayu, S., \& Sulistiawati. (2018). Hubungan Pengetahuan dan Sikap dengan Perilaku Caring Perawat di Rumah Sakit. Faletehan Health Journal. Volume 5 (2). Pages: 77-83. DOI: https://journal.Ippm-stikesfa.ac.id

Rika. (2013). Perilaku Caring Perawat dalam Melakukan Asuhan Keperawatan pada Pasien di Ruang Rawat Inap RSUD Dr. Tengku Mansyur Tanjungbalai. Skripsi Publised. Diakses dari: repository.usu.ac.id/bitstream/handle/12 $3456789 / 39084 /$ Cover.pdf? sequence $=7$ \&isAllowed $=\mathrm{y}$

Siwantoro, E. (2014). Efektifitas Pemberian Modul Caring Berbasis Kecerdasan Emosional Terhadap Peningkatan Kompetensi Keperawatan Mahasiswa Ners Dian Husada. Jurnal Keperawatan. Volume 13 (3). Pages: 92-98. Diakses dari:

https://www.scribd.com/document/373 356774/Efektifitas-Pemberian-Modul-

Caring-Berbasis-Kecerdasan-

Emosional-Terhadap-Peningkatan-

Kompetensi-Keperawatan-Mahasiswa-

Ners-Dian-Husada

Teting, B., Natalia, E., \& Ermayani, M. (2018). Teori Caring dan Aplikasi Dalam 
Pelayanan Keperawatan. Yogyakarta: ANDI (Anggota IKAPI).

Thadea, O., Suhartono, T., \& Putra, I. G. (2018). The Relationship Between Galen's Personality Type Theory and Emotional Intelligence Level. Biomolevular and Health Science Journal. Volume 1 (2). Pages : 80-84. DOI: https://ejournal.unair.ac.id/BHSJ
e-ISSN : 2685-7154

Volume 2, No. 2, Oktober 2020

Available online at http://ejournal.unklab.ac.id/index.php/kjn

Zees, R. F. (2011). Analisis Faktor Budaya Organisasi Yang Berhubungan dengan Perilaku Caring Perawat Pelaksana di Ruang Rawat Inap RSUD. Prof. Dr. H. Aloei Saboe Kota Gorontalo. Skripsi Publised. Diakses dari:

http://lontar.ui.ac.id/file?file=digital $/ 20$ 282247-

T\%20Rini\%20Fahriani\%20Zees.pdf 